Article

\title{
Ammonium Fertilizer Reduces Nitrous Oxide Emission Compared to Nitrate Fertilizer While Yielding Equally in a Temperate Grassland
}

\author{
Niharika Rahman * and Patrick J. Forrestal
}

Citation: Rahman, N.; Forrestal, P.J. Ammonium Fertilizer Reduces Nitrous Oxide Emission Compared to Nitrate Fertilizer While Yielding Equally in a Temperate Grassland. Agriculture 2021, 11, 1141.

https://doi.org/10.3390/ agriculture11111141

Academic Editor: Catherine Hénault

Received: 6 October 2021

Accepted: 12 November 2021

Published: 14 November 2021

Publisher's Note: MDPI stays neutra with regard to jurisdictional claims in published maps and institutional affiliations.

Copyright: (c) 2021 by the authors. Licensee MDPI, Basel, Switzerland. This article is an open access article distributed under the terms and conditions of the Creative Commons Attribution (CC BY) license (https:// creativecommons.org/licenses/by/ $4.0 /)$.
Crops, Environment and Land Use Programme, Soils, Land Use and Environment Department, Teagasc, Johnstown Castle, Y35 TC97 Co. Wexford, Ireland; patrick.forrestal@teagasc.ie

* Correspondence: niharika.rahman@teagasc.ie

\begin{abstract}
Emissions of nitrous oxide $\left(\mathrm{N}_{2} \mathrm{O}\right)$, a potent greenhouse gas, are a challenge associated with application of nitrogen $(\mathrm{N})$ fertilizers to soil. However, $\mathrm{N}$ source selection can play a role in reducing these emissions. Nitrous oxide emissions were measured from ammonium (ammonium sulfate) and nitrate (calcium nitrate) fertilizers over one year in temperate grassland using the closed static chamber method. Nitrogen was applied at a system representative rate of $220 \mathrm{~kg} \mathrm{ha}^{-1} \mathrm{y}^{-1}$ in six split applications. Cumulative annual $\mathrm{N}_{2} \mathrm{O}-\mathrm{N}$ emissions were $0.29 \mathrm{~kg} \mathrm{ha}^{-1}$ for the control, $1.07 \mathrm{~kg} \mathrm{ha}^{-1}$ for the ammonium fertilizer and significantly higher at $2.54 \mathrm{~kg} \mathrm{ha}^{-1}$ for the nitrate fertilizer. The annual emission factor (EF) for the ammonium fertilizer was $0.35 \%$ vs $1.02 \%$ for the nitrate fertilizer, a $66 \%$ reduction in the EF for ammonium vs nitrate and a 2.9 times higher EF for nitrate compared with ammonium. No difference in grass yield or $\mathrm{N}$ uptake was detected between fertilizers. This study shows that an ammonium fertilizer produces the same yield and $\mathrm{N}$ efficiency as a nitrate fertilizer with lower $\mathrm{N}_{2} \mathrm{O}$ emissions. The results also demonstrate that the nitrate portion of fertilizers is a key factor in $\mathrm{N}_{2} \mathrm{O}$ emissions in temperate grassland. This work is the first of its kind detailing the annual EF of both a solely ammonium-N and a solely nitrate-N fertilizer we could find.
\end{abstract}

Keywords: nitrogen fertilizer; ammonium sulfate; calcium nitrate; emission factor; yield

\section{Introduction}

Nitrous oxide is a long-lived ozone-depleting greenhouse gas (GHG) with a high global warming potential, it has approximately 300 times greater heat-trapping capacity than carbon dioxide [1]. Nitrous oxide is the prime contributor to ozone layer depletion in the stratosphere [2], a problem which must be addressed by reducing of $\mathrm{N}_{2} \mathrm{O}$ emissions rapidly. Over the last 150 years, atmospheric concentrations of $\mathrm{N}_{2} \mathrm{O}$ have reached unprecedented levels, increasing from 270 parts per billion ( $\mathrm{ppb}$ ) to $335 \mathrm{ppb}$ [3]. The Intergovernmental panel on climate change (IPCC) estimated that agriculture contributes about 60 to $70 \%$ of total global anthropogenic $\mathrm{N}_{2} \mathrm{O}$ emissions, mainly due to nitrogen $(\mathrm{N})$ fertilizer use and emissions from animal waste. This is owing to the presence of readily available N [4]. To feed the world's growing population, many agricultural systems require the frequent application of mineral $\mathrm{N}$ fertilizers to achieving high crop yield in non-leguminous species [5]. The $\mathrm{N}$ uptake by crops of applied mineral $\mathrm{N}$ is frequently low [6,7]. Global annual application of $\mathrm{N}$ is in excess of $100 \mathrm{Tg} \mathrm{N}$ [3], of which is estimated that more than $50 \mathrm{Tg}$ of $\mathrm{N}$ lost from the system through various loss pathways. IPCC estimates the emission factor (EF) of $1 \%$ from the application of mineral $\mathrm{N}$ fertilizer in the soil and strategies to reduce $\mathrm{N}_{2} \mathrm{O}$ emissions are urgently needed.

Temperate grasslands that are fertilized for grazing or cutting contribute more than $10 \%$ of the total global anthropogenic GHG emissions [8]. More than two-thirds of the land area in Ireland is covered by agricultural/natural grasslands which is the highest proportion in Europe (62\%) [9]. As agriculture in Ireland produces $90 \%$ of national $\mathrm{N}_{2} \mathrm{O}$ emissions and fertilizer accounts for $38 \%$ of these emissions the selection of fertilizers with 
low emissions is critically important for reducing on-farm emissions. In Ireland, calcium ammonium nitrate (CAN) accounts for approximately $37 \%$ of $\mathrm{N}$ applied, urea approximately $15 \%$ [10] with the remainder being applied in combination with other nutrients such as phosphorus $(\mathrm{P})$ and potassium $(\mathrm{K})$ with varying nitrate to ammonium-N ratios in the final product.

Nitrous oxide fluxes from the soil surface originate primarily from the nitrificationdenitrification process in the soil [11]. During nitrification, aerobic microbial populations convert ammonium $\left(\mathrm{NH}_{4}{ }^{+}\right)$to nitrate $\left(\mathrm{NO}_{3}{ }^{-}\right)$. Thereafter, $\mathrm{NO}_{3}{ }^{-}$can be converted to $\mathrm{N}_{2} \mathrm{O}$ by anaerobic microbial populations via denitrification. Synthesis and emission of $\mathrm{N}_{2} \mathrm{O}$ can occur in both steps (nitrification and denitrification) by microbial processes depending on the soil conditions (temperature, texture, structure, water availability and $\mathrm{pH}$ ), decomposable organic material and availability of reactive $\mathrm{N}$ [11]. Nitrogen fertilization increases the mineral $\mathrm{N}\left(\mathrm{NH}_{4}{ }^{+}-\mathrm{N}\right.$ and $\left.\mathrm{NO}_{3}{ }^{-}-\mathrm{N}\right)$ availability in the soil which is a positive for crop growth. However, these increases enhance nitrification-denitrification processes, which are responsible for the production of $\mathrm{N}_{2} \mathrm{O}$ [11]. The form of $\mathrm{N}$ applied to soil can be a determining factor in $\mathrm{N}_{2} \mathrm{O}$ loss. Denitrification is the direct source of $\mathrm{N}_{2} \mathrm{O}$ loss from nitrate fertilizers, while both nitrification and denitrification processes can be involved in $\mathrm{N}_{2} \mathrm{O}$ emissions from the ammonium-N sources [12]. Although both processes can contribute to the $\mathrm{N}_{2} \mathrm{O}$ emission from ammonium- $\mathrm{N}$ sources, several studies make the case that denitrification is the dominant process from soils when the water-filled pore space (WFPS) is higher than $70 \%$ [12]. Therefore, it is reasonable that the application of nitrate- $\mathrm{N}$ sources could promote greater $\mathrm{N}_{2} \mathrm{O}$ emissions than ammonium sources in poorly drained soils ( $>70 \%$ WFPS), particularly in temperate grasslands with regular rainfall such as those found in Ireland.

Cowan et al. [13] reviewed a dataset of $\mathrm{N}_{2} \mathrm{O}$-EFs from 21 separate studies carried out on arable land and managed grasslands across the UK and Ireland over the past 20 years. This study showed that ammonium nitrate (AN) and CAN, which both contain $\mathrm{NO}_{3}{ }^{-}-\mathrm{N}$ and $\mathrm{NH}_{4}{ }^{+}-\mathrm{N}$ in a 50:50 ratio on an $\mathrm{N}$ basis, were the largest $\mathrm{N}_{2} \mathrm{O}$ emitter of the fertilizer types examined. They also found that urea treated with inhibitors showed lower $\mathrm{N}_{2} \mathrm{O}$ emissions. This is in agreement with the results of studies in Irish grassland [14-16] that also found the highest losses from CAN fertilizer in the wet temperate grassland soils in Ireland. To reduce $\mathrm{N}$ loss in the form of $\mathrm{N}_{2} \mathrm{O}$ emissions, Harty et al. [14] proposed switching fertilizer formulation from CAN to urea fertilizer with the inclusion of a urease inhibitor and potentially also a nitrification inhibitor. However, in practice about half of the $\mathrm{N}$ in Ireland is applied as N, P and $\mathrm{K}$ blends or compounds. Compound fertilizers result from the intentional mixing of two or more nutrients in various percentages, contain the complete three macronutrients. These compounds contain varying proportions of total $\mathrm{N}$ content delivered as $\mathrm{NH}_{4}{ }^{+}-\mathrm{N}$, from as little as $53 \%$ of $\mathrm{N}^{-} \mathrm{NH}_{4}{ }^{+}-\mathrm{N}$ to as much as $95 \%$ of total $\mathrm{N}$ delivered as $\mathrm{NH}_{4}{ }^{+}-\mathrm{N}$. While $\mathrm{N}_{2} \mathrm{O}-\mathrm{EFs}$ exist for CAN which these do not well describe the emissions from compound fertilizers as some contain little $\mathrm{NO}_{3}{ }^{-}-\mathrm{N}$ due to their formulation. As far the authors are aware, no studies have measured the direct $\mathrm{N}_{2} \mathrm{O}$ emissions of a nitrate only or an ammonium only fertilizer over a full year to generate an annual emission factor. This is a significant knowledge gap for the development of abatement strategies, for our understanding of the relative weighting of the $\mathrm{NO}_{3}{ }^{-}-\mathrm{N}$ and the $\mathrm{NH}_{4}{ }^{+}-\mathrm{N}$ portions in driving $\mathrm{N}_{2} \mathrm{O}$ losses from ammonium nitrate or compound fertilizers. For emission inventory calculations it is clear that $\mathrm{N}_{2} \mathrm{O}$ losses from several blended/compound products are not best characterized by either CAN/AN or urea emission factors which are abundant [17]. The direct comparison of fully ammonium with fully nitrate fertilizers is very scarce. In a recent work, Gebremichael et al. [17] performed a shortterm experiment of three months, and the authors make the case that ammonium-based compound fertilizers have the potential to reduce $\mathrm{N}_{2} \mathrm{O}$ emissions compare to nitrate-based fertilizers and suggested a long-term study to capture the yearly $\mathrm{N}_{2} \mathrm{O}-\mathrm{EF}$. In the present study, an ammonium and a nitrate $\mathrm{N}_{2} \mathrm{O}-\mathrm{EF}$ is measured which can be used to provide new information to characterize differences in $\mathrm{N}_{2} \mathrm{O}$ emissions between $\mathrm{NO}_{3}{ }^{-}-\mathrm{N}$ and $\mathrm{NH}_{4}{ }^{+}-\mathrm{N}$ in temperate grassland. The current information is potentially of important use in inven- 
tory calculations of emissions from compound/blended N, P, K fertilizers based on their $\mathrm{NO}_{3}{ }^{-}-\mathrm{N}: \mathrm{NH}_{4}{ }^{+}-\mathrm{N}$ ratio. The specific research questions are (i) what is the effect of applying an ammonium and a nitrate fertilizer on $\mathrm{N}_{2} \mathrm{O}$ emissions? and (ii) what is the effect of providing nutrients in ammonium vs nitrate form on grass dry matter yield, $\mathrm{N}$ uptake and recovery? We hypothesized that (i) the ammonium fertilizer will have lower $\mathrm{N}_{2} \mathrm{O}$ emissions than the nitrate fertilizer and (ii) that $\mathrm{N}$ source will affect dry matter yield and $\mathrm{N}$ uptake, these hypotheses are tested.

\section{Materials and Methods}

\subsection{Study Site}

The field experiment was conducted at the permanent grassland site located at Johnstown Castle, Co. Wexford, Ireland $\left(52^{\circ} 17^{\prime} \mathrm{N} ; 6^{\circ} 30^{\prime} \mathrm{W}\right)$ during the period 11 February 2020 to 11 February 2021 capturing a full yearly cycle. The plot was in long-term pasture with perennial ryegrass (Lolium perenne L.) prior to the study. No field cropping took place and it was reseeded with perennial ryegrass in 2018. Generally, the site received $150-200 \mathrm{~kg} \mathrm{~N} \mathrm{ha}^{-1} \mathrm{y}^{-1}$ of $\mathrm{N}$ fertilizer in five equal splits between March and September in previous years. A basal application of $\mathrm{P}, \mathrm{K}$, and $\mathrm{S}$ was also applied in line with soil test recommendations in the year of the study. In the year immediately preceding the experiment, no fertilizers were applied as the site was being prepared for experimental use. Before the experimental setup in 2020, eight soil samples from 0-10 cm depth were collected from the experimental plots to determine the soil characteristics. A summary of soil physical and chemical characteristics are presented in Table 1 . The soil is moderately drained sandy loam classified as a Stagnic Cambisol $[18,19]$ with $14 \%$ clay, $52 \%$ sand, $34 \%$ silt, $5.3 \%$ organic matter and a water $\mathrm{pH} 6.2$.

Table 1. The initial physical and chemical characteristics of the study site.

\begin{tabular}{|c|c|}
\hline Soil Properties & Values \\
\hline Sand (\%) & 52 \\
\hline Silt (\%) & 34 \\
\hline Clay (\%) & 14 \\
\hline Textural class & Sandy loam \\
\hline Bulk density $\left(\mathrm{g} \mathrm{cm}^{-3}\right)$ & 1.4 \\
\hline Soil pH & 6.2 \\
\hline Organic matter (\%) & 5.97 \\
\hline Organic carbon $(\%)$ & 2.1 \\
\hline Total N (mg kg $\left.{ }^{-1}\right)$ & 48 \\
\hline $\mathrm{NH}_{4}{ }^{+}-\mathrm{N}\left(\mathrm{mg} \mathrm{kg}^{-1}\right)$ & 4.6 \\
\hline $\mathrm{NO}_{3}{ }^{-}-\mathrm{N}\left(\mathrm{mg} \mathrm{kg}^{-1}\right)$ & 11 \\
\hline Morgan's P (mg/L) & 7.37 \\
\hline Morgan's K (mg/L) & 118 \\
\hline Morgan's Mg (mg/L) & 97 \\
\hline $\mathrm{SO}_{4}^{2-}(\mathrm{mg} / \mathrm{L})$ & 1.2 \\
\hline
\end{tabular}

\subsection{Experimental Set Up}

The experimental design was a randomized complete block design with five replicates per treatment. The chamber size was $40 \mathrm{~cm} \times 40 \mathrm{~cm}$ and it was to this area fertilizer treatments were applied. The experimental treatments were ammonium sulfate (AS $\left.\left(\left(\mathrm{NH}_{4}\right)_{2} \mathrm{SO}_{4}\right), 21 \% \mathrm{~N}\right)$ and calcium nitrate $\left(\mathrm{CN}\left(\mathrm{Ca}\left(\mathrm{NO}_{3}\right)_{2}\right), 17 \% \mathrm{~N}\right)$ fertilizers and a zero $\mathrm{N}$ control. Fertilizers were applied in six split applications between February and September of 20 (11 February 2020), 40 (23 March 2020), 40 (27 April 2020), 40 (8 June 2020), 40 (13 July 2020) and 40 (2 September 2020) kg N ha ${ }^{-1}$ which corresponded to an annual application of $220 \mathrm{~kg} \mathrm{~N} \mathrm{ha}^{-1}$. Both fertilizers were granular products. Experimental plots received a basal application of $\mathrm{P}, \mathrm{K}$, and $\mathrm{S}$ during the experimental period in line with soil test recommendations to ensure that these nutrients were not limiting. 


\section{3. $\mathrm{N}_{2} \mathrm{O}$ Sampling and Analysis and Calculation of Flux}

Fluxes of $\mathrm{N}_{2} \mathrm{O}$ were measured for 12 months using the closed static chamber technique [16]. The chambers were made of stainless steel which comprised of a chamber base measuring $0.4 \mathrm{~m} \times 0.4 \mathrm{~m}$ wide and $0.1 \mathrm{~m}$ high. The chambers were inserted into the ground to a depth of $\geq 5 \mathrm{~cm}$, with a corresponding lid of the height of $0.1 \mathrm{~m}$. The base chambers were inserted into the soil before the experiment commenced and left in position for the duration of the experiment.

Gas sampling was commenced between 9.00 and $11.00 \mathrm{~h}$, as this was reported as the best time to represent the average daily flux [20]. For gas sampling, three samples were taken at 0,15 and $30 \mathrm{~min}$ after closing the chamber, using a $20 \mathrm{~mL}$ syringe and were injected into pre-evacuated $10 \mathrm{~mL}$ gas vials. Gas samples were collected five times in the first week after $\mathrm{N}$ application, three times in the second week. Gas sampling was reduced to twice per week for the next two weeks and once per week until the next $\mathrm{N}$ application. Once the $\mathrm{N}_{2} \mathrm{O}$ fluxes returned to baseline (control) levels over the winter period (November 2020-February 2021), gas samples were collected every two weeks.

The concentrations of $\mathrm{N}_{2} \mathrm{O}$ were analyzed using a gas chromatograph (Bruker Scion 456) equipped with a $63 \mathrm{Ni}$ electron capture detector (ECD). Gas samples were injected into GC using a Combi-PAL xt ${ }^{\circledR}$ auto-sampler (CTC Analytics AG, Zwingen, Switzerland). Daily fluxes were calculated using the following equation given by Smith and Conen [21]:

$$
F=\frac{\Delta C}{\Delta t} \times \frac{v}{A} \times \frac{M}{V} \times \frac{P}{P o} \times((273+T) / R)
$$

where $F$ is the daily flux rate of the gas studied $\left(\mathrm{g} \mathrm{m}^{-2}\right.$ day $\left.^{-1}\right), \Delta C / \Delta t$ is the slope of the line for $T_{0}, T_{15}$ and $T_{30}, \Delta C$ is the change in concentration in the chamber headspace during the enclosure period in ppbv, $\Delta t$ is the time interval $(15 \mathrm{~min}), v\left(\mathrm{~m}^{3}\right)$ and $A\left(\mathrm{~m}^{2}\right)$ are the chamber volume and the soil surface area respectively, $M$ is the molecular weight of the gas (44 for $\mathrm{N}_{2} \mathrm{O}$ ), $V$ is the volume occupied by $1 \mathrm{~mol}$ of the gas at standard pressure $(22.4 \mathrm{~L}$ ) and temperature, $P$ is the barometric pressure (mbar), $P o$ is the standard pressure (1013 mbar), and $T$ is the average temperature in Kelvin $\left({ }^{\circ} \mathrm{K}\right)$. The final $\mathrm{N}_{2} \mathrm{O}$ flux rate was presented as $\mathrm{kg} \mathrm{N} \mathrm{ha}^{-1}$ day $^{-1}$.

The cumulative emissions were calculated separately from the integration of the area under the curve of each measurement point. The area between two adjacent intervals on the measurement days was calculated using the trapezoid formula as follows [22]:

$$
A_{t(a b)}=\left(t_{b}-t_{a}\right) \times\left(F_{t a}+F_{t b}\right) / 2
$$

where $A_{t(a b)}$ is the area of the two adjacent intervals on the measurement days (in $\mathrm{kg} \mathrm{ha}^{-1}$ between $t_{a}$ and $\left.t_{b}\right), t_{a}$ and $t_{b}$ are the number of days from the start of the experiment of the two adjacent measurements, and $F_{t a}$ and $F_{t b}$ are the fluxes of the gas of interest $\left(\mathrm{kg} \mathrm{ha}^{-1} \mathrm{day}^{-1}\right)$ on $t_{a}$ and $t_{b}$.

The total cumulative emissions were calculated as the sum of the emissions $A_{t(a b)}$ for all time intervals.

The $\mathrm{N}_{2} \mathrm{O}-\mathrm{EF}$ s from $\mathrm{AS}$ and $\mathrm{CN}$ treatments were calculated using the equation proposed by the IPCC [23]:

$$
\mathrm{N}_{2} \mathrm{O}-E F=\left(\frac{\sum \mathrm{N}_{2} \mathrm{O}-\sum N_{C}}{N_{a}}\right) \times 100
$$

where $\sum N_{2} \mathrm{O}$ is the cumulative $\mathrm{N}_{2} \mathrm{O}-\mathrm{N}$ emissions $\left(\mathrm{kg} \mathrm{ha}^{-1}\right)$ from each treatment, $\sum N_{C}$ is the cumulative $\mathrm{N}_{2} \mathrm{O}-\mathrm{N}$ emissions $\left(\mathrm{kg} \mathrm{ha}^{-1}\right)$ from the control plot, and $\mathrm{N}_{a}$ is the amounts of $\mathrm{N}$ applied in the field expressed in $\mathrm{kg} \mathrm{N} \mathrm{ha}^{-1}$.

On each sampling day during the experimental period, soil moisture and atmospheric pressure (Garmin PSmap $64 \mathrm{~s}$ ) and soil temperature $(5 \mathrm{~cm}$ depth) were recorded. Air temperature and daily rainfall were also collected from the nearest $(\leq 1 \mathrm{~km})$ meteorological station. Water-filled pore space was calculated using the soil bulk density and the volumetric moisture content recorded each sampling day. 
Water-filled pore space (WFPS, \%) was calculated according to the following relationship.

Water-filled pore space $($ WFPS $)=100 \times($ volumetric moisture content $/$ total soil porosity $)$.

where total soil porosity $=(1-($ soil bulk density $/$ soil particle density $)) \times 100$ and the soil particle density was assumed to be $2.65 \mathrm{~g} \mathrm{~cm}^{-3}$.

\subsection{Grass Harvesting}

The chamber area was harvested six times between March to October, 2020 (23 March 2020, 21 April 2020, 4 June 2020, 8 July 2020, 28 September 2020 and 15 October 2020). At each harvesting date, the grass was cut to a height of $5 \mathrm{~cm}$ and removed. The total grass fresh weight per plot was recorded to determine grass yield and a subsample was collected to determine dry matter (DM) content and $\mathrm{N}$ uptake. Fresh subsamples of grass were weighed and dried at $70^{\circ} \mathrm{C}$ until reaching a constant weight. Once dried, grass dry weight was recorded to calculate dry matter (DM) and subsequently dried samples were ground and passed through a $2 \mathrm{~mm}$ sieve and used for further analysis. Nitrogen percentage was determined using a LECO combustion analyzer (St. Joseph, MI, USA).

Grass dry matter yield was calculated as:

Grass dry matter yield $\left(\mathrm{kg} \mathrm{ha}^{-1}\right)=($ Green grass weight $\times$ dry matter $(\%) \times$ plot size $) / 100$.

where dry matter $(\%)=($ Dry grass sample/wet grass sample $) \times 100$.

Total grass dry matter yield $\left(\mathrm{kg} \mathrm{ha}^{-1}\right)$ was calculated to combine the yield from six harvest. $\mathrm{N}$ uptake was calculated as:

$$
\mathrm{N} \text { uptake }\left(\mathrm{kg} \mathrm{ha}^{-1}\right)=(\text { Grass dry matter yield } \times \mathrm{N} \text { content }(\%)) / 100 \text {. }
$$

Total $\mathrm{N}$ uptake $\left(\mathrm{kg} \mathrm{ha}^{-1}\right)$ was calculated to combine the $\mathrm{N}$ uptake from six harvest. Apparent $\mathrm{N}$ recovery $(\%)$ was calculated as:

Apparent $\mathrm{N}$ recovery $(\%)=((\mathrm{N}$ uptake from the fertilized plot $-\mathrm{N}$ uptake from the control plot $) /$ Fertilizer $\mathrm{N}$ applied $) \times 100$.

\subsection{Statistical Analysis}

Statistical analyses were done using Statistical Analysis System (SAS) Proprietary Software version 9.4 (SAS Institute Inc., Cary, NC, USA). Homogeneity of variance was tested with the PROC GLM test of equality of error variance, and normal distribution was tested with the PROC UNIVARIATE test for normality. All the data met the assumptions without transformation. Differences between the treatments' effect on total cumulative $\mathrm{N}_{2} \mathrm{O}$ emission, grass dry matter yield and $\mathrm{N}$ uptake were examined by the analysis of variance (ANOVA), using general linear models (GLM) procedure in SAS. Significance was determined at an alpha level of 0.05 . In the cases where ANOVA was significant, all the means were compared using the F-protected least significant difference (LSD) test at the $95 \%$ confidence level.

\section{Results}

\subsection{Nitrous Oxide Emissions}

Nitrous oxide fluxes were measured from 11 February 2020 to 11 February 2021. Environmental conditions varied considerably during this period. The daily rainfall varied from 0 to $23 \mathrm{~mm}$ corresponding to water-filled pore space (WFPS) levels as high as 91\% (Figure 1). Such high WFPS levels are favorable to the coupled nitrification-denitrification process [24]. During the gas sampling, the soil temperature ranged between $2{ }^{\circ} \mathrm{C}$ and $26^{\circ} \mathrm{C}$. Annual rainfall was $1176 \mathrm{~mm}$ (February 2020-February 2021) compared to the long-term (2010-2020) average of $1035 \mathrm{~mm}$. The temporal dynamics of $\mathrm{N}_{2} \mathrm{O}$ flux are presented in Figure 1. Nitrous oxide dynamics over the sampling year were considerably affected by the fertilizer treatments (Figure 1a). Nitrous oxide fluxes started to increase directly after fertilizer application. Under 
the conditions of the study, daily $\mathrm{N}_{2} \mathrm{O}$ emissions ranged from 0.04 to $185 \mathrm{~g} \mathrm{~N}_{2} \mathrm{O}-\mathrm{N}$ ha ${ }^{-1} \mathrm{~d}^{-1}$ for the ammonium AS fertilizer and from 0.01 to $462 \mathrm{~g} \mathrm{~N}_{2} \mathrm{O}-\mathrm{N} \mathrm{ha}^{-1} \mathrm{~d}^{-1}$ for the nitrate $\mathrm{CN}$ fertilizer (Figure 1a). The most pronounced peaks in $\mathrm{N}_{2} \mathrm{O}$ emissions were associated with fertilizer applications and the magnitude of the peaks differed between fertilizer treatments. For both fertilized treatments, the highest peaks were obtained on the seventh day after the first fertilizer application in February, coinciding with WFPS values of $82 \%$ which is most favorable for denitrification [12] (Figure 1b). Under these conditions favoring denitrification the peak of $\mathrm{N}_{2} \mathrm{O}$ flux of $462 \mathrm{~g} \mathrm{~N}_{2} \mathrm{O}-\mathrm{N} \mathrm{ha}{ }^{-1} \mathrm{~d}^{-1}$ at day seven for $\mathrm{CN}$ treatment was more than double the peak associated AS treatment which was $185 \mathrm{~g} \mathrm{~N}_{2} \mathrm{O}-\mathrm{N} \mathrm{ha}^{-1} \mathrm{~d}^{-1}$. Nitrous oxide flux was higher for the first three splits of fertilizer application applied prior to May compared to the 4th, 5th and 6th fertilizer application due to the lower rainfall and the lower soil water content later in the growing season. During the summer period WFPS dropped to as low as $25 \%$ (Figure $1 \mathrm{~b}$ ). The average $\mathrm{N}_{2} \mathrm{O}$ flux for both fertilizer treatments (8.67 $\mathrm{g} \mathrm{N}_{2} \mathrm{O}-\mathrm{N} \mathrm{ha}^{-1}$ day $^{-1}$ for AS and $26.41 \mathrm{~g} \mathrm{~N}_{2} \mathrm{O}-\mathrm{N} \mathrm{ha}^{-1}$ day $^{-1}$ for $\mathrm{CN}$ ) in the period prior to the fourth fertilizer application on 8 July was considerably higher than the average in the period following the 4th, 5th and 6th split of fertilizer application $\left(2.15 \mathrm{~g} \mathrm{~N}_{2} \mathrm{O}-\mathrm{N} \mathrm{ha}{ }^{-1}\right.$ day $^{-1}$ for AS and $3.18 \mathrm{~g} \mathrm{~N}_{2} \mathrm{O}-\mathrm{N} \mathrm{ha}^{-1}$ day $^{-1}$ for $\mathrm{CN}$ ). The yearly average $\mathrm{N}_{2} \mathrm{O}$ flux for $\mathrm{CN}$ treatment was $13 \mathrm{~g} \mathrm{~N}_{2} \mathrm{O}-\mathrm{N} \mathrm{ha}^{-1}$ day $^{-1}$ which was 2.7 times higher than for the AS treatment $\left(4.9 \mathrm{~g} \mathrm{~N}_{2} \mathrm{O}-\mathrm{N} \mathrm{ha}^{-1}\right.$ day $\left.^{-1}\right)$. For comparison, the average daily $\mathrm{N}_{2} \mathrm{O}$ flux of the unfertilized control treatment was $0.96 \mathrm{~g} \mathrm{~N}_{2} \mathrm{O}-\mathrm{N} \mathrm{ha}^{-1}$ day $^{-1}$.
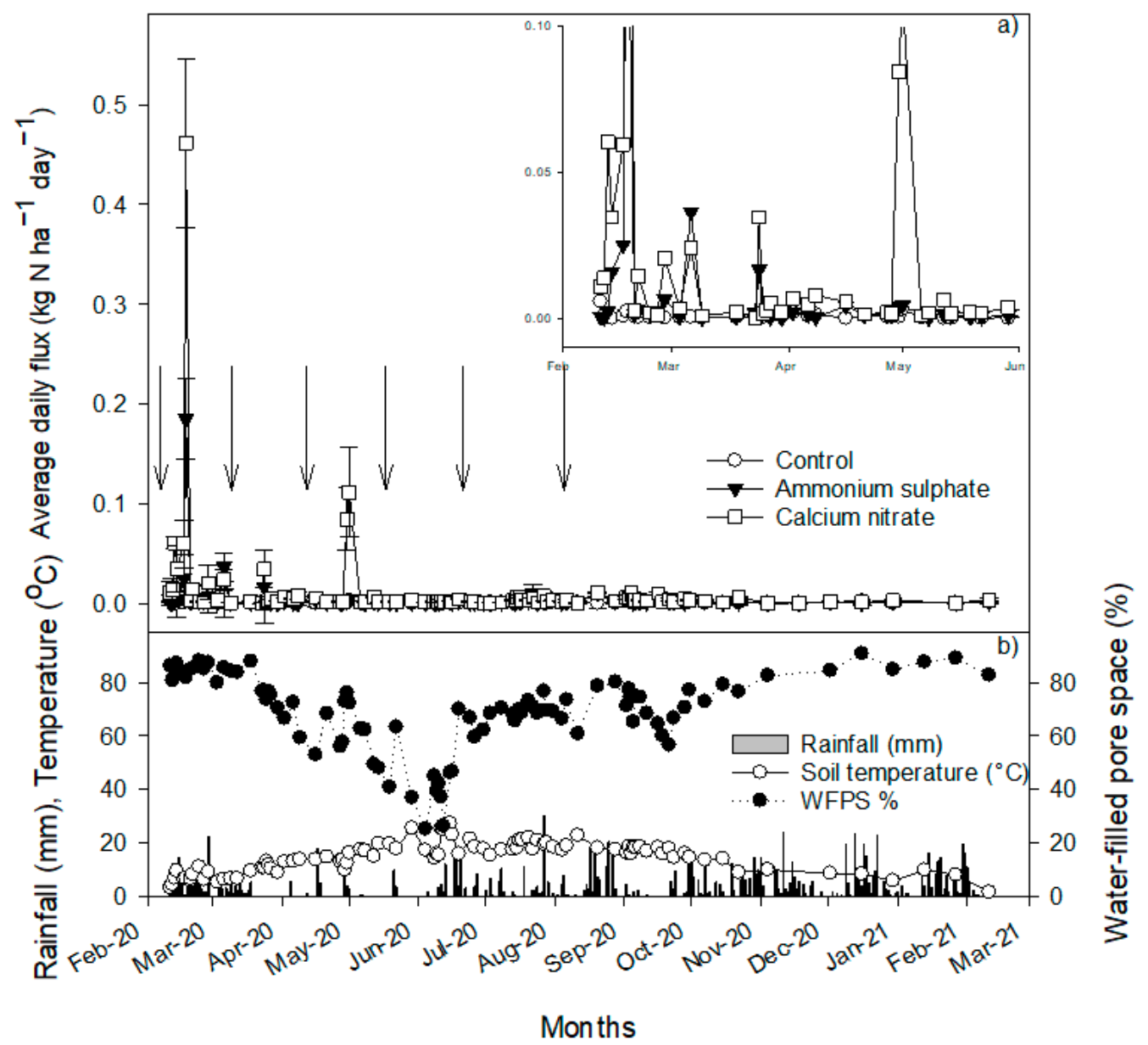

Figure 1. (a) Average $\mathrm{N}_{2} \mathrm{O}$ flux from the fertilizer treatments during the experimental period. Arrows indicate fertilizer application timing. The insert is an enlargement of the plot for improved visibility. Error bars indicate 1 SE $(n=5)$. (b) Average soil ( $5 \mathrm{~cm}$ depth) temperature, rainfall and water-filled pore space (WFPS) over the measurement period. 


\subsection{Cumulative Emissions and Emission Factors}

The total cumulative emission from nitrate $\mathrm{CN}$ fertilizer is significantly higher $(p \leq 0.05)$ than for the ammonium AS fertilizer and the zero $\mathrm{N}$ control treatment. Cumulative $\mathrm{N}_{2} \mathrm{O}$ emissions for the 365 day experimental period (Table 2) for the $\mathrm{CN}$ treatment was $2.54 \mathrm{~kg} \mathrm{ha}^{-1}$ compared to the AS treatment $\left(1.07 \mathrm{~kg} \mathrm{ha}^{-1}\right)$, net of the control a $66 \%$ reduction in $\mathrm{N}_{2} \mathrm{O}$ emission using an ammonium fertilizer compared using a nitrate fertilizer source. Additionally, the yearly emission factor which represents the percentage of the applied $\mathrm{N}$-fertilizer per year that has been lost in the form of $\mathrm{N}_{2} \mathrm{O}$ was lower for the ammonium AS fertilizer $(0.35 \%)$ compared to the nitrate $\mathrm{CN}$ treatment with an $\mathrm{EF}$ of $1.02 \%$. Thus, net of the control fertilizer associated $\mathrm{N}_{2} \mathrm{O}$ emissions were 2.9 times higher for nitrate compared with ammonium. The CN EF was similar to the IPCC default value for $\mathrm{N}$ fertilizers of $1 \%$ but the ammonium AS fertilizer was some $65 \%$ lower than the IPPC default.

Table 2. Total cumulative $\mathrm{N}_{2} \mathrm{O}$ emission and the emission factor for 365 days.

\begin{tabular}{ccc}
\hline Treatments & $\begin{array}{c}\text { Total Cumulative } \\
\mathbf{( k g ~ h a}^{-\mathbf{1}} \mathbf{)}\end{array}$ & Emission Factor (\%) \\
\hline Control & $0.29 \pm 0.12^{\mathrm{c}}$ & \\
Ammonium Sulfate & $1.07 \pm 0.12^{\mathrm{b}}$ & 0.35 \\
Calcium Nitrate & $2.54 \pm 0.15^{\mathrm{a}}$ & 1.02 \\
\hline
\end{tabular}

Cumulative emissions represent a mean \pm 1 standard error $(n=5)$. Mean comparison by F-protected LSD test $(p \leq 0.05)$; values with different letters within a column indicating significant differences between treatments.

\subsection{Grass Dry Matter Yield, N Uptake and Recovery}

Total dry matter yield and $\mathrm{N}$ uptake results show a significant difference between treatments (Table 3). AS and CN fertilizers produced significantly higher dry matter yield compared to the unfertilized control treatment. However, the $\mathrm{N}$ fertilizer treatments were not different from each other. As with dry matter yield, no significant differences were observed between the AS $\left(208 \mathrm{~kg} \mathrm{~N} \mathrm{ha}^{-1} \mathrm{y}^{-1}\right)$ and $\mathrm{CN}\left(207 \mathrm{~kg} \mathrm{~N} \mathrm{ha}^{-1} \mathrm{y}^{-1}\right)$ fertilizers for $\mathrm{N}$ uptake. Apparent $\mathrm{N}$ recovery was equivalent between fertilizers at $48 \%$ and $47 \%$ for AS and $\mathrm{CN}$ treatments, respectively.

Table 3. Annual dry matter yield, $\mathrm{N}$ uptake and $\mathrm{N}$ recovery for different treatments.

\begin{tabular}{cccc}
\hline Treatments & $\begin{array}{c}\text { Total Dry Matter Yield } \\
\left(\mathbf{k g ~ h a}^{-\mathbf{1}} \mathbf{y}^{\mathbf{- 1}} \mathbf{)}\right.\end{array}$ & $\begin{array}{c}\text { N Uptake } \\
\mathbf{( k g ~ h a - 1}^{-\mathbf{1}} \mathbf{)}\end{array}$ & $\begin{array}{c}\text { Apparent } \mathbf{~} \\
\text { Recovery (\%) }\end{array}$ \\
\hline Control & $6247 \pm 464^{\mathrm{b}}$ & $104 \pm 7^{\mathrm{b}}$ & \\
Ammonium sulfate & $12,412 \pm 594^{\mathrm{a}}$ & $208 \pm 10^{\mathrm{a}}$ & 48 \\
Calcium nitrate & $12,276 \pm 535^{\mathrm{a}}$ & $207 \pm 10^{\mathrm{a}}$ & 47 \\
\hline
\end{tabular}

Total dry matter yield and $\mathrm{N}$ uptake represent a mean \pm 1 standard error $(n=5)$. Mean comparison by F-protected LSD test $(p \leq 0.05)$; values with different letters within a column indicating significant differences between treatments.

\section{Discussion}

\subsection{Effect of Fertilizer N Formulation on Annual Emission Factor}

The Ammonium fertilizer (AS) resulted in a lower $\mathrm{N}_{2} \mathrm{O}$ emission compared to the nitrate fertilizer $(\mathrm{CN})$. The nitrate fertilizer $\mathrm{CN}$ contains $100 \%$ of delivered $\mathrm{N}$ in the nitrate form which increases soil $\mathrm{NO}_{3}{ }^{-}-\mathrm{N}$ concentrations and primes the soil system for denitrification loss of $\mathrm{N}_{2} \mathrm{O}$ if other factors particularly WFPS favor this loss pathway. Compared to $\mathrm{CN}$ fertilizer, AS fertilizer supplies $100 \%$ of applied $\mathrm{N}_{\text {in }} \mathrm{NH}_{4}{ }^{+}-\mathrm{N}$ form which is available for first the processes of nitrification and then denitrification. In both steps, $\mathrm{N}_{2} \mathrm{O}$ emission can occur. However, in this grassland soil decreased rather than increased $\mathrm{N}_{2} \mathrm{O}$ losses resulted from ammonium usage. Ammonium has to go through one extra step (nitrification) which may delay the overall production of $\mathrm{N}_{2} \mathrm{O}$ in the soil by limiting the soil nitrate pool available for denitrification. As nitrification is occurring, both ammonium and nitrate formed by nitrification is been taken up by plants in the case of the AS fertilizer. As a result, in the present study, AS $\left(1.07 \mathrm{~kg} \mathrm{ha}^{-1}\right)$ showed a significant reduction of cumulative annual 
$\mathrm{N}_{2} \mathrm{O}-\mathrm{N}$ emission compared to the nitrate source $\mathrm{CN}$ fertilizer $\left(2.54 \mathrm{~kg} \mathrm{ha}^{-1}\right)$ while producing the same yield and $\mathrm{N}$ recovery efficiency as the nitrate fertilizer (Table 3). Bremer [25] found that cumulative annual emissions of $\mathrm{N}_{2} \mathrm{O}-\mathrm{N}$ were $1.60 \mathrm{~kg} \mathrm{ha}^{-1}$ after application of $250 \mathrm{~kg}$ AS-N ha ${ }^{-1}$ in perennial ryegrass field near Manhattan, Kansas in the USA. The cumulative annual $\mathrm{N}_{2} \mathrm{O}$ emission from AS fertilizer was reported by Bremer [25] is 33\% higher than the present study, which could be affected by many factors (soil, temperature, rainfall, etc.). Bremer [25] mentioned that they irrigated the land after fertilization to incorporate fertilizer into the soil and reduce ammonia volatilization. Several other studies also reported the ammonia volatilization loss especially from urea applications from grass-based pasture [26,27]. There are also volatilization losses reported from fertilizers such as AS but the extend of volatilization loss is much less in AS (8\%) in comparison with urea $(15 \%)[27,28]$, nevertheless the ammonia loss potential should be assessed in any fertilizer strategy.

In the present study, a strong influence of soil moisture was observed after the first split application of fertilizer, at the time WFPS was at $82 \%$, which is favorable for denitrification. Under this condition the peak of $\mathrm{N}_{2} \mathrm{O}$ flux for the $\mathrm{CN}$ treatment was more than double the peak associated with AS treatment (Figure 1). However, in contrast to the present study, Soares et al. [29] found that $\mathrm{CN}$ fertilizer resulted in very low $\mathrm{N}_{2} \mathrm{O}$ emissions compared to urea in a sugarcane field in Brazil. They reported a maximum WFPS in the soil of $40 \%$ which is more favorable for nitrification [12]. They also mentioned an alternate explanation for the low $\mathrm{N}_{2} \mathrm{O}$ emissions in the $\mathrm{CN}$ treatment could be $\mathrm{NO}_{3}{ }^{-}$leaching. Nitrate is an anion which is mobile and vulnerable to leaching loss, while $\mathrm{NH}_{4}{ }^{+}$is a cation and not lost as easily from the soil a potential strong advantage in a moist temperate region such as Ireland where water quality is a pressing issue facing agriculture. Fixation of the $\mathrm{NH}_{4}{ }^{+}$ion by clay mineral interlayers can be increased by increasing the application of $\mathrm{NH}_{4}{ }^{+}$containing fertilizers in the soils which can be a way in building up an available $\mathrm{N}$ pool in soils to optimize crop recovery and minimize $\mathrm{N}$ losses into the environment [30]. Ammonium is taken up by plants for direct use in plant protein formation [31]. Therefore, it is often desirable to use ammonium fertilizers to retain $\mathrm{N}$ fertilizer in the plant-available $\mathrm{NH}_{4}{ }^{+}$ form to limit $\mathrm{NO}_{3}-$ leaching.

The nitrous oxide EF was $0.35 \%$ for the AS treatment which is $66 \%$ lower compared to the $\mathrm{CN}$ treatment in the present study. The $\mathrm{N}_{2} \mathrm{O}-\mathrm{EF}$ for the $\mathrm{CN}$ treatment was $1.02 \%$ which is very similar to the default value of $1 \%$ by IPCC Tier 1 [1]. Globally, the $\mathrm{N}_{2} \mathrm{O}-\mathrm{EF}$ for $\mathrm{N}$ fertilizers ranged from $0.01 \%$ to $6.70 \%$, and $75 \%$ of these EFs reported (or calculated) were in the range given by the IPCC for the Tier 1 default EF $(0.30-3 \%$, mean $1 \%$ [27]). Bouwman [32] analyzed the global values reporting that an average fertilizer-induced $\mathrm{N}_{2} \mathrm{O}$ emission is $1.25 \% \pm 1 \%$ of $\mathrm{N}$ applied. A recent meta-analysis based on Brazilian cropland done by Mazzetto et al. [27] reported the average $\mathrm{N}_{2} \mathrm{O}-\mathrm{EF}$ was $1.12 \%$, whereas a lower value was found when using AS ( $0.60 \%)$ fertilizer and a higher value from urea $(1.45 \%)$ fertilizer. The $\mathrm{N}_{2} \mathrm{O}-\mathrm{EF}$ for AS fertilizer presented by Mazzetto et al. [27] is $42 \%$ higher than that of the present study. The annual $\mathrm{N}_{2} \mathrm{O}$ loss from AS fertilizer in the present study in cool temperate maritime grassland showed $46 \%$ lower than the value $(0.65 \%)$ reported by Bremer [25] in the humid mid-Altantic region in Kansas, USA. From our knowledge the work of Bremer [25] is the only previous experiment where the annual $\mathrm{N}_{2} \mathrm{O}$ emissions were measured from AS fertilizer (250 $\left.\mathrm{kg} \mathrm{N} \mathrm{ha}^{-1} \mathrm{y}^{-1}\right)$ and it was conducted in turfgrass ecosystems in the USA [25]. However, control treatment was not included in their experiment which is necessary to derive $\mathrm{N}_{2} \mathrm{O}$-EF. Emission factors derived for pure nitrate fertilizers are very limited in the literature. Soares et al. [29] reported that only $0.04 \%$ of $\mathrm{N}_{2} \mathrm{O}$ was lost after the application of $120 \mathrm{~kg} \mathrm{ha}^{-1} \mathrm{CN}$ fertilizer after 278 days of the experiment from a sugarcane field in Brazil. However, in the present study, $220 \mathrm{~kg} \mathrm{ha}^{-1} \mathrm{CN}$ was applied and the experiment was conducted for 365 days giving a contrasting loss of $1.02 \%$. The only comparison of AS and $\mathrm{CN}$ we could find was by Zanatta et al. [33] conducted an experiment for 15 days with the application of $30 \mathrm{~kg} \mathrm{~N} \mathrm{ha}^{-1}$ in a cornfield in sub-tropical Porto Alegre, Brazil. They found that the application of $\mathrm{CN}$ and AS resulted in the losses of $1.03 \%$ and $0.45 \%$, respectively in this very short-term experiment. Their results followed a similar trend to those of our 365 day 
experiment. In contrast to the results of the present study, Bergstrom et al. [34] reported no differences in $\mathrm{N}_{2} \mathrm{O}$ emissions induced by urea, $\mathrm{AS}$ and $\mathrm{CN}$ fertilizers. However, due to a short 24 days of evaluation, this study may not capture the variability of $\mathrm{N}_{2} \mathrm{O}$ emissions and is also not be comparable with the present year-long study. As $\mathrm{N}_{2} \mathrm{O}$ emissions could be affected by many factors and some of the factors especially rainfall could be varied year to year. Harty et al. [14] found that a prolonged water saturation condition promoted longer lasting $\mathrm{N}_{2} \mathrm{O}$ emissions. Although the present study was lasted for one year, a multi year and site study for the development of more robust nitrate and ammonium EFs would be beneficial.

Urea, CAN and AN are the most commonly used straight fertilizers in the UK and Ireland [14-16,35-37]. A detailed meta-analysis done by Cowan et al. [13] reported that urea fertilizer had a lower $\mathrm{N}_{2} \mathrm{O}-\mathrm{EF}$ value $(\mathrm{EF}=$ average $0.6 \%$; range $0.5-0.7 \%$ ) compared with the AN (range 1.0-1.2\%) and CAN (range 0.7-1.3\%) fertilizers. Rahman et al. [16] reported the average EF for CAN was approximately 3.5 times higher than EFs from the urea formulations in Ireland. Krol et al. [15] also reported a higher annual $\mathrm{N}_{2} \mathrm{O}-\mathrm{EF}$ from CAN $(0.58 \%)$ compared with urea $(0.07 \%)$ and urea + urease inhibitor NBPT $(0.06 \%)$ in Ireland. However, in these studies, urea was compared with CAN fertilizer. CAN contains nitrate-N and ammonium-N in a 1:1 ratio. Therefore, the present study is unique in providing insight into the weighing of nitrate and ammonium separately in their relative contribution to $\mathrm{N}_{2} \mathrm{O}$ losses. This feature of the present work is not derived from previous studies in Irish grassland or indeed in the vast majority of $\mathrm{N}_{2} \mathrm{O}$ studies. The absence of separate nitrate and ammonium EFs hampers efforts to accurately quantify national emissions because in Ireland where for example compound or blended fertilizers containing other nutrients such as $\mathrm{P}$ in addition to $\mathrm{N}$ accounted for approximately half of all nutrient $\mathrm{N}$ sales [10]. The EFs generated in previous work for urea and CAN do not best represent these compound fertilizers with differing nitrate to ammonium ratios. A recently published short-term study by Gebremichael et al. [17] with artificial watering to promote emissions showed nitrate to ammonium ratios $\left(\mathrm{NO}_{3}{ }^{-}: \mathrm{NH}_{4}{ }^{+}=0.05,0.53,0.80,0.88\right)$ for the commonly used compound fertilizers (10-10-20, 18-06-12, 27-2.5-5 and 24-2.2-4.5). Emission measurements conducted in July and August 2021 showed an average $\mathrm{N}_{2} \mathrm{O}$ loss of $1.8 \%$ from ammonium-based $\left(\mathrm{NO}_{3}{ }^{-}: \mathrm{NH}_{4}{ }^{+}=0.05\right.$ and 0.53$)$ and $2.37 \%$ from nitrate-based $\left(\mathrm{NO}_{3}{ }^{-}: \mathrm{NH}^{+}=0.80\right.$ and 0.88$)$ compound fertilizers.

\subsection{Effect of Fertilizer $N$ on Annual Yield}

Ammonium sulfate produced the same level of yield as calcium nitrate but with significantly lower emissions and an annual emission factor that was $66 \%$ lower. A blanket application of $S$ was applied to ensure that $S$ limitations do not occur, and ammonium and nitrate nutrition resulted in the same grass yield. The nitrogen uptake of the AS treatment $\left(208 \mathrm{~kg} \mathrm{ha}^{-1} \mathrm{y}^{-1}\right)$ was also not significantly different from the $\mathrm{CN}$ treatment $\left(207 \mathrm{~kg} \mathrm{ha}^{-1} \mathrm{y}^{-1}\right)$. Plant fertilizer $\mathrm{N}$ requirement has been linked to soil nitrate levels [38]; however inorganic nitrate and ammonium ions are available for plant uptake. The current work demonstrates that ammonium nutrition incurred no yield or $\mathrm{N}$ uptake penalty compared to nitrate in a temperate grassland. Both mineralization of indigenous soil $\mathrm{N}$ resources and applied $\mathrm{N}$ inputs contribute to the plant-available $\mathrm{N}$ pool [31] and plants are able to assimilate $\mathrm{NH}_{4}{ }^{+}-\mathrm{N}, \mathrm{NO}_{3}{ }^{-}-\mathrm{N}$ and organic $\mathrm{N}$ forms [39]. From an energetic point of view, $\mathrm{NH}_{4}{ }^{+}$uptake and assimilation are less costly than that of $\mathrm{NO}_{3}{ }^{-}$[40]. This could constitute an advantage for plants that are very competitive for $\mathrm{NH}_{4}{ }^{+}$absorption. Previous studies have reported significant temperate grassland yield responses under cutting up to $400 \mathrm{~kg} \mathrm{~N} \mathrm{ha}^{-1}$ [41] indicating that in the present study the $\mathrm{N}$ rate was on the responsive part of the response curve and any disadvantage of either fertilizer would be expected to result in a reduced yield, which it did not, indicating similar performance.

Several studies also reported no difference in the biomass yield with regards to the effect of $\mathrm{N}$ fertilizer treatments and type in Irish grasslands [41,42]. A previous study by Forrestal et al. [41] found no significant difference in annual grass yield between CAN, urea and urea + NBPT (urease inhibitor) fertilizers; however, urea showed reduced N 
uptake. Harty et al. [42] also conducted experiments at three locations over two years (6 site-years) in Ireland and UK, covering a range of soils and climatic conditions, and found that CAN, urea + NBPT, urea + NBPT + dicyandiamide (NI), and urea produced equal annual dry matter yield. Our findings concerning ammonium and nitrate fertilizers similarly found no difference indicating that fertilizer $\mathrm{N}$ source is not a major factor affecting yield performance in temperature grassland. In the present study, the total yield across six harvests resulted in cumulative DM yields of $12.4,12.2$ and 6.2 tonnes $\mathrm{ha}^{-1} \mathrm{y}^{-1}$ for AS, $\mathrm{CN}$ and zero $\mathrm{N}$ treatment respectively. These values are comparable to the annual grass DM yield which was varied between 10 to 13 tonnes ha ${ }^{-1}$ for the application of $200 \mathrm{~kg} \mathrm{~N} \mathrm{ha}^{-1} \mathrm{y}^{-1}$ in Irish grass land [42]. Eveillard et al. [43] compared urea and AN applied to the same plots over multiple years and for individual years in France. They detected a statistically significant fertilizer type effect on total yield more frequently when urea and AN were applied over multiple years compared to where they were applied for a single year. Continuous application of $\mathrm{N}$ fertilizers can increase soil acidification in the reported order $\mathrm{AS}>\mathrm{NH}_{4} \mathrm{Cl}>$ AN > urea $[44,45]$. In the present study, calcium nitrate fertilizer has been used which contains calcium ions; however, we expect the likely effect of $\mathrm{Ca}$ on soil $\mathrm{pH}$ is minor compared to liming which is recommended to occur on a five-year cycle. These results point toward a need for long-term trial data to inform our understanding of relative fertilizer $\mathrm{N}$ performance along with multiple sites.

\section{Conclusions}

The ammonium AS fertilizer significantly reduced the yearly $\mathrm{N}_{2} \mathrm{O}$ emissions compared to the nitrate $\mathrm{CN}$ fertilizer without compromising grass yield or $\mathrm{N}$ uptake. Thus, ammonium fertilizers or compound fertilizers that contain a high proportion of $\mathrm{N}$ as ammonium represented an opportunity for decreasing $\mathrm{N}_{2} \mathrm{O}$ emission compared to nitrate fertilizers while sustaining yield in temperate grassland. The ammonium sulfate fertilizer is less leaching vulnerable, with lower $\mathrm{N}_{2} \mathrm{O}$ emission potential, while being more nutrient dense and producing similar yield compared to the calcium nitrate fertilizer. However, AS has a relatively higher acidifying potential and is likely to increase ammonia volatilization loss compared to nitrate. Approximately half of the total $\mathrm{N}$ applied in Ireland is applied as CAN or urea. The other half is made up of compound products with varying proportions of nitrate and ammonium ranging from total $\mathrm{N}$ delivery of $53 \%$ as ammonium-N to $95 \%$ as ammonium-N. Thus, the EFs from the separate ammonium and nitrate fertilizers reported in this study are needed and useful for emission inventory and mitigation strategy development. The currently available EFs for CAN (50\% ammonium-N), urea or urea with inhibitors do not best represent the emissions of the compound fertilizers. Our results suggest that applying ammonium fertilizers is an option to maintain grass yield and decreasing $\mathrm{N}_{2} \mathrm{O}$ losses.

Author Contributions: Conceptualization: N.R. and P.J.F.; methodology: N.R. and P.J.F.; data curation: N.R.; formal analysis: N.R.; investigation: N.R.; writing—original draft preparation: N.R.; writingreview and editing: N.R. and P.J.F.; supervision: P.J.F. All authors have read and agreed to the published version of the manuscript.

Funding: Teagasc and partial support of the Department of Agriculture, Food and the Marine, Ireland, under call funding instruments I to V, 2017, Grant number 17F207.

Institutional Review Board Statement: Not applicable.

Informed Consent Statement: Not applicable.

Acknowledgments: We acknowledge technical assistance from the technicians and researchers at Teagasc, Soils, Land Use and Environment Department, Johnstown Castle. We especially like to thank Gareth Gillen for analyzing gas samples; Wendy Pierce and Carmel OConnor for analyzing grass samples; Brendan Healy for analyzing soil samples; John Murphy and Cathal Redmond for helping during the experimental setup and technical support during the experiment. 
Conflicts of Interest: The authors declare that they have no known competing financial interests or personal relationships that could have appeared to influence the work reported in this paper.

\section{References}

1. IPCC. Climate Change 2014: The Physical Science Basis. Contribution of Working Group I to the Fifth Assessment Report of the Intergovernmental Panel on Climate Change; Stocker, T.F., Qin, D., Plattner, G.K., Tignor, M.B., Allen, S.K., Boschung, J., Nauels, A., Xia, Y., Bex, V., Midgley, P.M., et al., Eds.; Cambridge University Press: Cambridge, UK; New York, NY, USA, 2014.

2. Ravishankara, A.; Daniel, J.S.; Portmann, R.W. Nitrous oxide $\left(\mathrm{N}_{2} \mathrm{O}\right)$ : The dominant ozone-depleting substance emitted in the 21st century. Science 2009, 326, 123-125. [CrossRef]

3. Lu, C.; Tian, H. Global nitrogen and phosphorus fertilizer use for agriculture production in the past half century: Shifted hot spots and nutrient imbalance. Earth Syst. Sci. Data 2017, 9, 181-192. [CrossRef]

4. Tian, H.; Xu, R.; Canadell, J.G.; Thompson, R.L.; Winiwarter, W.; Suntharalingam, P.; Davidson, E.A.; Ciais, P.; Jackson, R.B.; Janssens-Maenhout, G. A comprehensive quantification of global nitrous oxide sources and sinks. Nature 2020, 586, 248-256. [CrossRef]

5. Mosier, A.; Kroeze, C. Potential impact on the global atmospheric $\mathrm{N}_{2} \mathrm{O}$ budget of the increased nitrogen input required to meet future global food demands. Chem. Glob. Chang. Sci. 2000, 2, 465-473. [CrossRef]

6. Lassaletta, L.; Billen, G.; Grizzetti, B.; Anglade, J.; Garnier, J. 50 year trends in nitrogen use efficiency of world cropping systems: The relationship between yield and nitrogen input to cropland. Environ. Res. Lett. 2014, 9, 105011. [CrossRef]

7. Raun, W.R.; Solie, J.B.; Johnson, G.V.; Stone, M.L.; Mullen, R.W.; Freeman, K.W.; Thomason, W.E.; Lukina, E.V. Improving nitrogen use efficiency in cereal grain production with optical sensing and variable rate application. Agron. J. 2002, 94, 815-820. [CrossRef]

8. Emmet-Booth, J.P.; Dekker, S.; O'Brien, P. Climate Change Mitigation and the Irish Agriculture and Land Use Sector; Working Paper on Climate Change Advisory Council: Dublin, Ireland, 2019; Available online: https://www.climatecouncil.ie/media/ climatechangeadvisorycouncil/Working\%20Paper\%20on\%20Agriculture\%20and\%20Land\%20Use.pdf (accessed on 20 February 2021).

9. CSO. Statistical Yearbook of Ireland 2019; Farm Structure Survey-Survey Coverage; Central Statistics Office: Dublin, Ireland, 2020. Available online: https://www.cso.ie/en/releasesandpublications/ep/p-syi/statisticalyearbookofireland2020/ (accessed on 25 March 2021).

10. DAFM. How Much and What Fertiliser Was Sold in 2019? Department of Agriculture, Food and the Marine: Dublin, Ireland, 2020. Available online: https:/ / www.agriland.ie/farming-news/how-much-and-what-fertiliser-was-sold-in-2019/ (accessed on 28 September 2020).

11. Davidson, E.A.; Swank, W.T. Environmental parameters regulating gaseous nitrogen losses from two forested ecosystems via nitrification and denitrification. Appl. Environ. Microbiol. 1986, 52, 1287-1292. [CrossRef] [PubMed]

12. Butterbach-Bahl, K.; Dannenmann, M. Denitrification and associated soil $\mathrm{N}_{2} \mathrm{O}$ emissions due to agricultural activities in a changing climate. Curr. Opin. Environ. Sustain. 2011, 3, 389-395. [CrossRef]

13. Cowan, N.; Carnell, E.; Skiba, U.; Dragosits, U.; Drewer, J.; Levy, P. Nitrous oxide emission factors of mineral fertilisers in the UK and Ireland: A Bayesian analysis of 20 years of experimental data. Environ. Int. 2020, 135, 105366. [CrossRef] [PubMed]

14. Harty, M.A.; Forrestal, P.J.; Watson, C.; McGeough, K.; Carolan, R.; Elliot, C.; Krol, D.; Laughlin, R.J.; Richards, K.G.; Lanigan, G. Reducing nitrous oxide emissions by changing $\mathrm{N}$ fertiliser use from calcium ammonium nitrate (CAN) to urea based formulations. Sci. Total Environ. 2016, 563, 576-586. [CrossRef]

15. Krol, D.; Forrestal, P.; Wall, D.; Lanigan, G.; Sanz-Gomez, J.; Richards, K. Nitrogen fertilisers with urease inhibitors reduce nitrous oxide and ammonia losses, while retaining yield in temperate grassland. Sci. Total Environ. 2020, 725, 138329. [CrossRef] [PubMed]

16. Rahman, N.; Richards, K.G.; Harty, M.A.; Watson, C.J.; Carolan, R.; Krol, D.; Lanigan, G.J.; Forrestal, P.J. Differing effects of increasing calcium ammonium nitrate, urea and urea+ NBPT fertiliser rates on nitrous oxide emission factors at six temperate grassland sites in Ireland. Agric. Ecosyst. Environ. 2021, 313, 107382. [CrossRef]

17. Gebremichael, A.W.; Rahman, N.; Krol, D.J.; Forrestal, P.J.; Lanigan, G.J.; Richards, K.G. Ammonium-Based Compound Fertilisers Mitigate Nitrous Oxide Emissions in Temperate Grassland. Agronomy 2021, 11, 1712. [CrossRef]

18. FAO. World Reference Base for Soil Resources 2014. In International Soil Classification System for Naming Soils and Creating Legends for Soil Maps; World Soil Resources Reports No. 106; FAO: Rome, Italy, 2014.

19. Rahman, N.; Henke, C.; Forrestal, P.J. Efficacy of the Nitrification Inhibitor 3, 4 Dimethylpyrazol Succinic Acid (DMPSA) when Combined with Calcium Ammonium Nitrate and Ammonium Sulphate-A Soil Incubation Experiment. Agronomy 2021, 11, 1334. [CrossRef]

20. Rahman, N.; Islam, S.; Magid, J.; Giller, K.; Bruun, T.; de Neergaard, A. Variations in the Diurnal Flux of Greenhouse Gases from Oil Palm Plantation in Indonesia; Conference on International Research on Food Security; Natural Resource Management and Rural Development: Berlin, Germany, 2015.

21. Smith, K.A.; Cresser, M.S. Measurement of Trace Gases, I: Gas Analysis, Chamber Methods, and Related Procedures. In Soil and Environmental Analysis; CRC Press: London, UK, 2003; pp. 394-433.

22. Rahman, N.; Bruun, T.B.; Giller, K.E.; Magid, J.; van de Ven, G.W.; de Neergaard, A. Soil greenhouse gas emissions from inorganic fertilizers and recycled oil palm waste products from Indonesian oil palm plantations. Glob. Chang. Biol. Bioenergy 2019, 11, 1056-1074. [CrossRef] 
23. IPCC. 2006 IPCC Guidelines for National Greenhouse Gas Inventories. In Agriculture, Forestry and Other Land Use; Eggleston, H.S., Buendia, L., Miwa, K., Ngara, T., Tanabe, K., Eds.; Prepared by the National Greenhouse Gas Inventories Programme; IGES: Kanagawa, Japan, 2006; Volume 4.

24. Grundmann, G.; Rolston, D. A water function approximation to degree of anaerobiosis associated with denitrification. Soil Sci. 1987, 144, 437-441. [CrossRef]

25. Bremer, D.J. Nitrous oxide fluxes in turfgrass: Effects of nitrogen fertilization rates and types. J. Environ. Qual. 2006, 35, 1678-1685. [CrossRef]

26. Forrestal, P.J.; Harty, M.; Carolan, R.; Lanigan, G.; Watson, C.; Laughlin, R.J.; McNeill, G.; Chambers, B.; Richards, K.G. Ammonia emissions from urea, stabilized urea and calcium ammonium nitrate: Insights into loss abatement in temperate grassland. Soil Use Manag. 2016, 32, 92-100. [CrossRef]

27. Mazzetto, A.M.; Styles, D.; Gibbons, J.; Arndt, C.; Misselbrook, T.; Chadwick, D. Region-specific emission factors for Brazil increase the estimate of nitrous oxide emissions from nitrogen fertiliser application by 21\%. Atmos. Environ. 2020, $230,117506$. [CrossRef]

28. IPCC. 2019 Refinement to the 2006 IPCC Guidelines for National Greenhouse Gas Inventories, 4 (Chapter 11). In Agriculture, Forestry and Other Land Use; Eggleston, H.S., Buendia, L., Miwa, K., Ngara, T., Tanabe, K., Eds.; Prepared by the National Greenhouse Gas Inventories Programme; IGES: Kanagawa, Japan, 2019; Volume 4.

29. Soares, J.R.; Cassman, N.A.; Kielak, A.M.; Pijl, A.; Carmo, J.B.; Lourenço, K.S.; Laanbroek, H.J.; Cantarella, H.; Kuramae, E.E. Nitrous oxide emission related to ammonia-oxidizing bacteria and mitigation options from $\mathrm{N}$ fertilization in a tropical soil. Sci. Rep. 2016, 6, 1-11.

30. Nieder, R.; Benbi, D.K.; Scherer, H.W. Fixation and defixation of ammonium in soils: A review. Biol. Fertil. 2011, 47, 1-14. [CrossRef]

31. Boudsocq, S.; Niboyet, A.; Lata, J.C.; Raynaud, X.; Loeuille, N.; Mathieu, J.; Blouin, M.; Abbadie, L.; Barot, S. Plant preference for ammonium versus nitrate: A neglected determinant of ecosystem functioning? Am. Nat. 2012, 180, 60-69. [CrossRef]

32. Bouwman, A. Direct emission of nitrous oxide from agricultural soils. Nutr. Cycl. Agroecosyst. 1996, 46, 53-70. [CrossRef]

33. Zanatta, J.A.; Bayer, C.; Vieira, F.C.; Gomes, J.; Tomazi, M. Nitrous oxide and methane fluxes in South Brazilian Gleysol as affected by nitrogen fertilizers. Rev. Bras. Cienc. Solo 2010, 34, 1653-1665. [CrossRef]

34. Bergstrom, D.; Tenuta, M.; Beauchamp, E. Nitrous oxide production and flux from soil under sod following application of different nitrogen fertilizers. Commun. Soil Sci. Plant Anal. 2001, 32, 553-570. [CrossRef]

35. Akiyama, H.; Yan, X.; Yagi, K. Evaluation of effectiveness of enhanced-efficiency fertilizers as mitigation options for $\mathrm{N}_{2} \mathrm{O}$ and $\mathrm{NO}$ emissions from agricultural soils: Meta-analysis. Glob. Chang. Biol. 2010, 16, 1837-1846. [CrossRef]

36. Bell, M.; Cloy, J.; Topp, C.; Ball, B.; Bagnall, A.; Rees, R.; Chadwick, D. Quantifying $\mathrm{N}_{2} \mathrm{O}$ emissions from intensive grassland production: The role of synthetic fertilizer type, application rate, timing and nitrification inhibitors. J. Agric. Sci. 2016, 154, 812-827. [CrossRef]

37. Cardenas, L.; Bhogal, A.; Chadwick, D.; McGeough, K.; Misselbrook, T.; Rees, R.; Thorman, R.; Watson, C.J.; Williams, J.; Smith, K. Nitrogen use efficiency and nitrous oxide emissions from five UK fertilised grasslands. Sci. Total Environ. 2019, 661, 696-710. [CrossRef]

38. Forrestal, P.J.; Meisinger, J.; Kratochvil, R. Winter wheat starter nitrogen management: A preplant soil nitrate test and site-specific nitrogen loss potential. Soil Sci. Soc. Am. J. 2014, 78, 1021-1034. [CrossRef]

39. Marschner, H. Marschner's Mineral Nutrition of Higher Plants; Academic Press: London, UK, 2011.

40. Salsac, L.; Chaillou, S.; Morot-Gaudry, J.-F.; Lesaint, C.; Jolivet, E. Nitrate and ammonium nutrition in plants. Plant Physiol. Biochem. 1987, 25, 805-812.

41. Forrestal, P.J.; Harty, M.A.; Carolan, R.; Watson, C.; Lanigan, G.; Wall, D.; Hennessy, D.; Richards, K.G. Can the agronomic performance of urea equal calcium ammonium nitrate across nitrogen rates in temperate grassland? Soil Use Manag. 2017, 33, 243-251. [CrossRef]

42. Harty, M.A.; Forrestal, P.J.; Carolan, R.; Watson, C.J.; Hennessy, D.; Lanigan, G.; Wall, D.; Richards, K.G. Temperate grassland yields and nitrogen uptake are influenced by fertilizer nitrogen source. Agron. J. 2017, 109, 1-9. [CrossRef]

43. Eveillard, P.; Lambert, M.; Herve, M.; Bouthier, A.; Champolivier, L.; Marquis, S.; Rocca, C.; Roussel, D. (Eds.) Comparison of Urea and Ammonium Nitrate in Long-Term Trials: Synthesis of Ten Years of Experimentation. In Proceedings of the International Fertiliser Society, Cambridge, UK, 12 December 2014; International Fertiliser Society: Leek, UK, 2014.

44. Schroder, J.L.; Zhang, H.; Girma, K.; Raun, W.R.; Penn, C.J.; Payton, M.E. Soil acidification from long-term use of nitrogen fertilizers on winter wheat. Soil Sci. Soc. Am. J. 2011, 75, 957-964. [CrossRef]

45. Stone, D.L.; Whitney, D.; Janssen, K.; Long, J. Soil properties after twenty years of fertilization with different nitrogen sources. Soil Sci. Soc. Am. J. 1991, 55, 1097-1100. [CrossRef] 